\title{
Epidemiological Characterization Of SARS-Cov-2 Infection in Children and Adolescents in Cape Verde - Analysis of The First Five Months of The Pandemic
}

\author{
Maria da Luz Lima Mendonça ${ }^{1 *}$, Janice de Jesus Xavier Soares ${ }^{2}$ and Ngibo Fernandes ${ }^{3}$ \\ ${ }^{1}$ Master's in health and Development, Department of Research, Science and Training of the National Institute of Public Health, Africa \\ ${ }^{2}$ Degree in Statistics and Information Management, Department of the National Health Observatory of the National Institute of Public Health, Africa \\ ${ }^{3}$ Master in Infectious Diseases, Degree in Medicine, Department of the National Health Observatory of the National Institute of Public Health, Africa \\ *Corresponding author: Maria da Luz Lima Mendonça, Master's in health and Development, Department of Research, Science and \\ Training of the National Institute of Public Health, Praia, Republic of Cape Verde, Africa.
}

To Cite This Article: Maria da Luz Lima Mendonça, Janice de Jesus Xavier Soares, Ngibo Fernandes, Epidemiological Characterization Of SARSCov-2 Infection in Children and Adolescents in Cape Verde - Analysis of The First Five Months of The Pandemic. Am J Biomed Sci \& Res. 2021 - 12(3). AJBSR.MS.ID.001746. DOI: 10.34297/AJBSR.2021.12.001746.

Received: 眥 December 18, 2020; Published: 鴜 March 22, 2021

\begin{abstract}
Introduction: The first confirmed case of SARS-CoV-2 infection in Cabo Verde was registered on March 18, 2020. Most of the confirmed cases were observed in adults, with the highest prevalence in patients between 20 and 39 years.

Objective: Identify the epidemiological characteristics of children and adolescents diagnosed with SARS-CoV2 infection in Cape Verde during the first five (5) months of the epidemic in Cabo Verde.

Methodology: The current study is observational and descriptive, covering 662 children and adolescents diagnosed with Covid-19 in Cape Verde in the first five months of the epidemic. The data were collected in the case registration database of the National Institute of Public Health. Data analysis was performed using SPSS version 22.

Results: During the study period, 662 children and adolescents were diagnosed with COVID-19 in Cape Verde. The majority, 254 (53.8\%) were female, 131 (27.8\%) were aged between 10 to 14 years, 394 (83.5\%) lived on the island of Santiago, 262 (55.5\%) in the municipality of Praia, and $344(72.9 \%)$ are in institutional internment. No severe cases or deaths were recorded at the time analysis.

Conclusions: Children and adolescents were less affected by COVID-19 in Cape Verde. Study results may contribute to a better understanding of SARS-CoV-2 infection in the child population in Cabo Verde.
\end{abstract}

Key words: Cabo Verde; Coronavirus; COVID-19; SARS-CoV-2; Children; Adolescents

\section{Introduction}

In December 2019, health services in Wuhan, Hubei province, China, began to detect an increase in cases of pneumonia of unknown origin that was later identified and designated as SARSCoV-2 (Severe Acute Respiratory Syndrome Coronavirus) [1]. Due to the worldwide spread of infection, the World Health Organization (WHO) declared the infection by SARS-CoV-2 on January 31, 2020, as a public health emergency of an international publ SARS-CoV-2 ich health event [2], and the pandemic situation was confirmed by WHO [3]. Cape Verde is a country located in West Africa with just over five hundred thousand inhabitants. It is an archipelago that has ten islands, one of which is uninhabited. The first case of COVID-19 was identified on March 19, 2020, and the date of this study, seven of the nine inhabited islands had already reported cases of infection by SARS-CoV-2 [4]. 
Five months after the start of the pandemic in Cape Verde, children up to 18 years old represented $19.85 \%$ of the total cases registered in the country [5]. To date, there are no studies that characterize the clinical and epidemiological aspects of COVID19 in children in Cape Verde. There are partial data on the disease burden in children aged 10 to 18 years, obtained from the seroepidemiological study results carried out from June 26 to July 4 by the National Institute of Public Health and partners [6]. The survey findings pointed to a low prevalence (4\%) of infection in the general Cape Verdean population; however, the population aged 10 to 19 was responsible for $40 \%$ of the positive results [7]. There is a need to understand the pediatric population's epidemiological characteristics better to implement targeted protection and prevention measures.

\section{Objectives}

\section{General}

Identify the epidemiological characteristics of children and adolescents diagnosed with SARS-CoV2 infection in Cape Verde.

\section{Specific}

a. Describe the geographical distribution of COVID 19 cases in the pediatric population in Cape Verde.

b. Characterize the profile of children affected by SARSCoV-2 infection.

\section{Methodology}

The current study is a descriptive observational study with a quantitative approach. The study was carried out using information from the COVID-19 database of the National Institute of Public Health, containing information obtained from test results carried out in the virology laboratories of the same institution. All patients under 18 years of age diagnosed with SARS-CoV2 infection by the real-time reverse transcriptase-polymerase chain reaction (RT-PCR) method between March 19 and August 19, 2020, were included in the analysis. Epidemiological data included the date of notification, date of diagnosis, hospital discharge date, and outcome of the case.

The researchers analyzed the databases in Excel and extracted demographic data, including information about, age, gender, municipality, island, country of residence, and nationality.

\section{Statistical analysis}

The data were analyzed using the Excel spreadsheet and the Statistical Package for the Social Sciences software (SPSS, v. 22). The study population was characterized by sex/gender, age group, municipality, and the island of notification, diagnosis date, and discharge date.

\section{Study Design}

Study population and sample size determination. All individuals under the age of 18 diagnosed with SARS-CoV-2 infection by the PCR-RT molecular detection method, residing in Cabo Verde from March 19, 2020, to August 19, 2020, were included. The study included a total of 662 children.

\section{Ethical aspects}

All ethical principles were observed in the analysis of information.

\section{Results}

As of August 19, 2020, 662 children diagnosed with COVID-19 were registered and distributed in almost all the islands of the archipelago, except for the islands of Fogo and Brava (Figure 1).

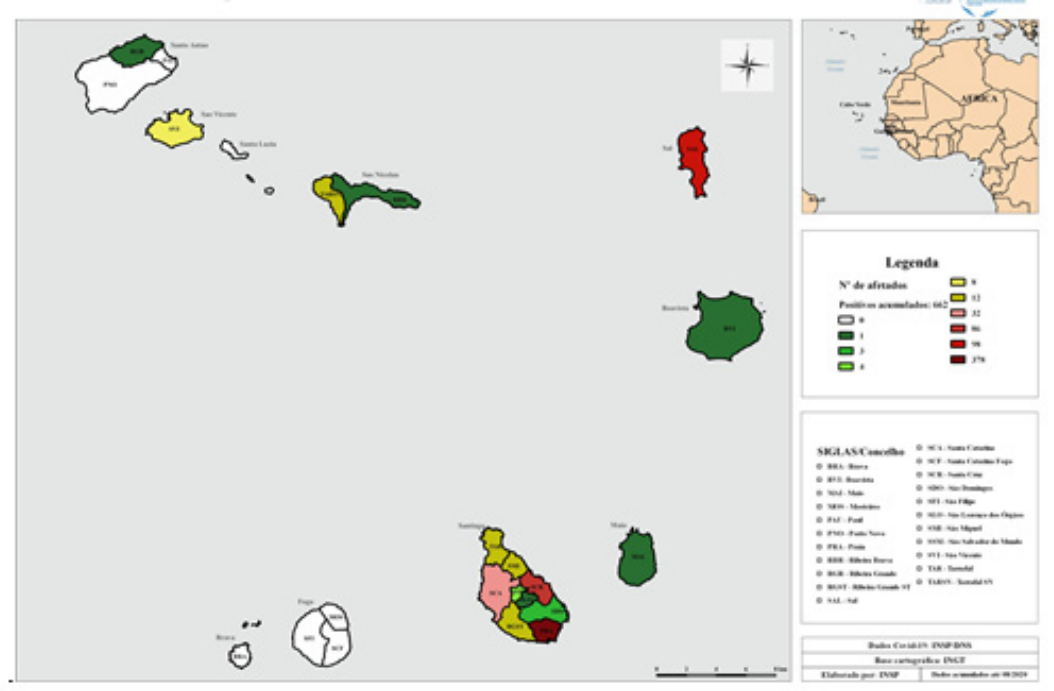

Figure: Distribution of confirmed cases of COVID19 in children up to 18 years of age in Caobo Verde as of August $19,2020$. 
Regarding the sex of children diagnosed with COVID-19, 357 (53.9\%) of the observed cases were female, and 305 (46.1\%) were male (Table 1). As for the age groups, 26 (3.9\%) under one year of age, 261 (39.4\%) were between 1 to 4 years old, 117 (17.7 \%) were between 5 and 9 years old, 134 (20.2\%) corresponded to the age group between 10 and 14 years old, while 124 (18.7\%) were 15 or more years old (Table 2).

Table 1.

\begin{tabular}{|c|c|c|}
\hline Sexo & Frequency & Percentage \\
\hline Masculino & 305 & 46.1 \\
\hline Feminino & 357 & 53.9 \\
\hline Total & 662 & 100.0 \\
\hline
\end{tabular}

Table 2.

\begin{tabular}{|c|c|c|}
\hline Idade & Frequency & Percentage \\
\hline Menores de 1 ano & 26 & 3.9 \\
\hline 1 a 4 anos & 261 & 39.4 \\
\hline 5 a 9 anos & 117 & 17.7 \\
\hline 10 a 14 anos & 134 & 20.2 \\
\hline 15 ou mais anos & 124 & 18.7 \\
\hline Total & 662 & 100.0 \\
\hline
\end{tabular}

Table 3.

\begin{tabular}{|c|c|c|}
\hline Ilha de residência & Frequency & Percentage \\
\hline Santo Antão & 1 & 0.2 \\
\hline São Vicente & 8 & 1.2 \\
\hline São Nicolau & 13 & 2.0 \\
\hline Sal & 98 & 14.8 \\
\hline Boavista & 1 & 0.2 \\
\hline Maio & 1 & 0.2 \\
\hline Santiago & 540 & 81.6 \\
\hline Total & 662 & 100.0 \\
\hline
\end{tabular}

Table 4.

\begin{tabular}{|c|c|c|}
\hline Concelho de residência & Frequency & Percentage \\
\hline Ribeira Grande & 1 & 0.2 \\
\hline São Vicente & 8 & 1.2 \\
\hline Ribeira Brava & 1 & 0.2 \\
\hline Tarrafal São Nicolau & 12 & 1.8 \\
\hline Sal & 98 & 14.8 \\
\hline Boavista & 1 & 0.2 \\
\hline Maio & 1 & 0.2 \\
\hline Tarrafal & 12 & 1.8 \\
\hline Santa Catarina & 32 & 4.8 \\
\hline Santa Cruz & 86 & 13.0 \\
\hline Praia & 378 & 57.1 \\
\hline São Domingos & 3 & 0.5 \\
\hline São Miguel & 12 & 1.8 \\
\hline
\end{tabular}

\begin{tabular}{|c|c|c|}
\hline São Salvador do Mundo & 4 & 0.6 \\
\hline São Lourenço dos Órgãos & 1 & 0.2 \\
\hline Ribeira Grande de Santiago & 12 & 1.8 \\
\hline Total & 662 & 100.0 \\
\hline
\end{tabular}

Table 5.

\begin{tabular}{|c|c|c|c|c|c|c|c|}
\hline & March & April & May & June & July & August & Total \\
\hline $\begin{array}{c}\text { Femi- } \\
\text { nin }\end{array}$ & 2 & 10 & 34 & 87 & 136 & 88 & 357 \\
\hline $\begin{array}{c}\text { Mas- } \\
\text { culin }\end{array}$ & 1 & 8 & 28 & 86 & 107 & 75 & 305 \\
\hline Total & 3 & 18 & 62 & 173 & 243 & 163 & 662 \\
\hline
\end{tabular}

The data showed that $540(81.6 \%)$ of the children resided on the island of Santiago, 98 (14.8\%) on the island of Sal, 13 (2\%) in São Nicolau, 8 (1.2\%) São Vicente, 1 (0.2\%) Santo Antão, 1 (0.2\%) Boavista and $1(0.2 \%)$ island of Maio (Table 3$)$. In regard to the municipality of residence, it was observed that the majority [378 $(57.1 \%)]$ of the children resided in the municipality of Praia, 98 (14.8\%) followed by the municipality of Sal, 86 (13\%) Santa Cruz, 32 (4.8\%) Santa Catarina, 12 (1.8\%) São Miguel, 12 (1.8\%) Tarrafal de São Nicolau, 12 (1.8\%) Tarrafal, 12 (1.8\%) Ribeira Grande de Santiago, 8 (1.2\%) São Vicente, 4 (0.6\%) São Salvador do Mundo, 3 (0.5\%) São Domingos. The municipalities of Ribeira Grande, Ribeira Brava, Boavista, Maio and São Lourenço dos Órgãos, reported, 1 (0.2\%), respectively (Table 4$)$.

Data showed that in the first three months of the pandemic, only 75 children with SS-COV2 infection were registered. There was a considerable increase in the number of cases in the observed population from June 2020 (Table 5).

\section{Discussion of Results}

Five months after the start of the pandemic in Cape Verde, children up to 18 years of age represented $19.85 \%$ of the total cases registered in the country. The first series of tests carried out at the epicenter of the pandemic pointed out that the virus affected children. However, adults were disproportionately affected compared to children [8]. In the same period, consequent studies had shown that children rarely developed complications, and most had mild symptoms of the disease $[9,10]$ and low lethality rates compared to adults $[11,12]$. A multi-center European study also demonstrated this trend of low morbidity, lethality, and mild to moderate disease forms in most of the children observed [12].

The low number of infections in children at the beginning of the pandemic led to speculation about whether children were at lower risk of infection from the virus [13]. It was also suggested that this could be associated with the fact that children were less exposed to the virus at the beginning of the pandemic [11]. Most of the children observed in previous studies were part of a family 
cluster $[12,13]$.

\section{Study Limitations}

The present study has several limitations. First and foremost, only data of confirmed cases obtained from databases at the central level were reviewed. Clinical processes and complementary exams, and treatment were not discussed in the present study.

\section{Funding Sources}

The study did not receive any financial support.

\section{Authors Contributions}

Mendonça, MLL; Fernandes, NM, were responsible for the conception, study design, and literature review. Fernandes, NM, was responsible for data collection. Soares JJX was responsible for the treatment, statistical analysis, and preparation of the statistical report. All authors contributed to the writing of the article and agreed with the decision to publish it.

\section{Disclaimer of Liability}

The appraisals expressed in this article include the study results and the authors' opinions and not the official position of the National Institute of Public Health or the National Directorate of Health of the Ministry of Health and Social Security of Cabo Verde.

\section{Conflict of Interest}

The authors declare that there is no conflict of interest in carrying out the present study.

\section{References}

1. WHO (2020b) Naming the coronavirus disease (COVID-19) and the virus that causes it.

2. WHO (2020a) IHR Emergency Committee on Novel Coronavirus (2019-
nCoV) WHO Director-General's Statement on IHR Emergency Committee on Novel Coronavirus (2019-NCoV).

3. WHO (2020c) WHO Director-General's opening remarks at the media briefing on COVID-19-2020. WHO Director-General's Opening Remarks at the Media Briefing on COVID-19-2020.

4. Confirmado Primeiro Caso De Covid-19 Na Praia. Ilhas, Expresso Das. [Ed.] Sara Almeida. Praia: S.N., 20 De Julho De 2020, Expresso Das Ilhas.

5. Cabo Verde. Governo: www.covid19.cv

6. Insp (2020) Inquérito Sero-Epidemiológico Final_29_07_2020. Instituto Nacional De Saude Publica.

7. Cabo Verde. Resolução no 63/2020.Boletim Oficial Ia série.

8. Li Q Guan X, Wu P, Wang X, Zhou L, et al. (2020) Early Transmission Dynamics in Wuhan, China, of Novel Coronavirus-Infected Pneumonia. N Engl J Med 382(13): 1199-1207.

9. Kam KQ, Yung CF, Cui L, Tzer Pin Lin R, Mak TM, et al. (2020) A Well Infant with Coronavirus Disease 2019 With High Viral Load. Clin Infect Dis 71(15): 847-849.

10. Zhu L, Wang J, Huang R, Liu L, Zhao H, et al. (2020) Clinical characteristics of a case series of children with coronavirus disease 2019. Pediatr Pulmonol 55(6): 1430-1432.

11. Dong Y, Mo X, Hu Y (2020) Epidemiological characteristics of 2143 pediatric patients with 2019 coronavirus disease in China. Pediatrics 58(4): 712-713.

12. Götzinger F, Santiago García B, Noguera Julián A, Lanaspa M, Lancella L, et al. (2020) COVID-19 in children and adolescents in Europe: a multinational, multicentre cohort study. The Lancet Child and Adolescent Health 4(9): 653-661.

13. Xu Y, Li X, Zhu B, Liang H, Fang C, et al. (2020) Characteristics of pediatric SARS-CoV-2 infection and potential evidence for persistent fecal viral shedding. Nat Med 26(4): 502-505. 